\title{
KUALITAS KIMIA DAN ORGANOLEPTIK BURGER IKAN TUNA YANG DISUBTITUSI DENGAN TEPUNG BUAH MENGKUDU (Morinda citrifolia)
}

\section{CHEMICAL QUALITY AND ORGANOLEPTICS OF TUNA FISH BURGER IN SUBTITUTION WITH CULTIVATION FLOUR (Morinda citrifolia)}

\author{
Evi Huzaibah ${ }^{1}$, Minarny Gobel ${ }^{2}$ dan Asrawaty ${ }^{1 *}$ \\ ${ }^{1}$ Program Studi Teknologi Hasil Pertanian, Fakultas Pertanian, Universitas Alkhairaat, \\ Jl. Diponegoro No. 39, Palu 94221, Indonesia \\ ${ }^{2}$ Program Studi Peternakan Universitas Tadulako, Palu, Indonesia.
}

\begin{abstract}
ABSTRAK
Penelitian ini bertujuan untuk mengetahui pengaruh penambahan tepung mengkudu sebagai subtitusi tepung tapioka terhadap kadar protein, kadar air, dan kadar abu serta sifat organoleptik burger ikan tuna. Penelitian ini menggunakan Rancangan Acak Lengkap (RAL) dan Rancangan Acak Kelompok (RAK). Adapun perlakuan percobaan adalah : B1 (0\% tepung mengkudu $+15 \%$ tepung tapioka), B2 (2,5\% tepung mengkudu $+12,5 \%$ tepung tapioka), B3 (5\% tepung mengkudu $+10 \%$ tepung tapioka), B4 (7,5\% tepung mengkudu $+7,5 \%$ tepung tapioka). Untuk mengetahui pengaruh perlakuan ,maka dilakukan analisis ragam dan bila perlakuan berpengaruh nyata dilanjut dengan uji lanjut BNT. Berdasarkan hasil penelitian dapat disimpulkan bahwa penambahan tepung mengkudu sebagai subtitusi tepung tapioka sampai 7,5\% dapat meningkatkan kadar protein burger ikan tuna sebesar 14,87\%, kadar air 71,07\%, dan kadar abu 2,07\%, serta pemberian aroma, rasa, warna, dan tekstur relatif sama pada semua perlakuan.
\end{abstract}

Katakunci: Kualitas kimia, organoleptik, subtitusi, mengkudu, burger ikan tuna

\section{ABSTRACT}

The purpose of this research is to know the effect of addition of noni flour as substitution of tapioca flour to protein content, moisture content, and ash content and organoleptic nature of tuna burger. This study used Completely Randomized Design (RAL) and Randomized Block Design (RAK). The experimental treatment were: B1 (0\% noni flour $+15 \%$ tapioca flour $), B 2(2.5 \%$ noni flour $+12.5 \%$ tapioca flour), B3 (5\% noni flour $+10 \%$ tapioca flour), B4 7.5\% noni flour $+7.5 \%$ tapioca flour). To know the effect of treatment, then the analysis of variance and if the treatment has real effect continued with BNT advanced test. Based on the result of the research, it can be concluded that the addition of noni flour as substitution of tapioca flour to $7.5 \%$ can increase the protein tuna burger protein by $14.87 \%$, moisture content $71.07 \%$ and ash content $2.07 \%$, and aroma, taste, color, and texture are relatively the same on all treatments.

Keywords: Quality chemistry, organoleptic, substitution, noni, tuna fish burger

\section{Pendahuluan}

Burger telah dikenal sejak ribuan tahun yang lalu, bermula dari pedagang asal Timur Tengah yang menikmati daging kambing cincang di salah satu restoran di Hamburg, Jerman. Hamburg adalah pusat perdagangan dan juga

\footnotetext{
${ }^{*}$ Penulis Korespondensi.

E-mail: asrawaty@unisapalu.ac.id

Telp: +62-81327226461
}

sebagai tempat berkumpulnya para pedagang asal Arab (Hardiman, 2011).

Konsumsi burger diseluruh dunia amat populer karena rasanya yang lezat, bergizi, dan praktis. Seiring dengan berkembangnya zaman, burger diolah secara inovatif, sekarang ini kita kenal rice burger yang berasal dari Jepang yang mengganti roti dengan nasi yang dicetak bulat tengahnya diberi daging, sayuran, dan saus (Sudarmadji, $d k k .$, 1989).

Burger sangat populer hingga kini, penggemarnya tidak sedikit. Tua muda, kecil 


\section{Jurnal Pengolahan Pangan 3 (1) 1-8}

dewasa, menyukai burger. Karena itu banyak yang menjadikan burger sebagai salah satu komoditas dalam usaha jasa boga dan ternyata burger juga bisa membuat orang kaya raya, karena bisnis ini sangat menjanjika dan suda menjadi makanan berbagai kalangan karena banyak dijual oleh jaringan restoran cepat saji atau cafe-cafe, bahkan burger saat ini sudah lazim dijajakan disekolah-sekolah menggunakan gerobak sepeda atau stand semi permanen (Sarwono, 2010).

Pemasakan burger dapat dilakukan dengan cara pemanggangan, penggorengan, atau pemasakan dengan microwave. Tujuan pemasakan adalah menyatukan bahan, memantapkan warna, menginaktitfakan mikroba, dan suhu pemasakan. Penggorengan menyebabkan kehilangan air sekitar 5\% dan kehilangan lemak yang cukup besar, tergantung metode pemasakan (Abustam dan Ali, 2004).

\section{Tujuan dan Kegunaan}

Penelitian ini bertujuan untuk mempelajari kualitas kimia burger ikan tuna yang menggunakan tepung buah mengkudu sehingga dapat diterima oleh konsumen. Adapun kegunaan dari penelitian ini sebagai sumber informasi yang nantinya dapat menjadi rujukan untuk penelitian selanjutnya.

\section{Metode Penelitian}

Bahan yang digunakan tepung mengkudu, tepung tapioka, garam, masako, bawang putih dan merah, merica, air es, daging ikan tuna, mentega dan roti.

Adapun alat yang digunakan yaitu timbangan, aluminium foil, oven, pisau, talenan, blender, panci analitik, dan loyang.

Penelitian ini dilaksanakan dengan menggunakan Rancangan Acak Lengkap (RAL) dan Rancangan Acak Kelompok (RAK), dengan perlakuan sebagai berikut:

B1 $=15 \%$ (Tepung Tapioka) $+0 \%$ (Tepung Mengkudu) $\mathrm{B} 2=12.5 \%$ (TepungTapioka) $+2.5 \%$ (TepungMengkudu $)$ B3 $=10 \%$ (Tepung Tapioka) $+5 \%$ (Tepung Mengkudu) B $4=7.5 \%$ (Tepung Tapioka) $+7.5 \%$ (Tepung Mengkudu)

Setiap perlakuan diulang 4 kali, sehingga terdapat 16 unit percobaan. Untuk mengetahui pengaruh perlakuan yang dicobakan maka dilakukan analisis ragam dan bila perlakuan menunjukan pengaruh nyata maka dilanjutkan dengan Uji Beda Nyata Terkecil (BNT). Adapun formulasi bahan penyusunan dan kombinasi perlakuan pada Tabel 1 berikut:
e-ISSN : 2621-6973

p-ISSN : 2527-5631

Tabel 1. Formulasi bahan penyusun dan kombinasi perlakuan

\begin{tabular}{lllll}
\hline \multicolumn{1}{c}{ Perlakuan } & P0 & P1 & P2 & P3 \\
\hline Tepung tapioka (g) & 15 & 12.5 & 10 & 7.5 \\
Tepung mengkudu (g) & 0 & 2.5 & 5 & 7.5 \\
Daging ikan (g) & 64 & 64 & 64 & 64 \\
Bawang putih+ merah (g) & 3 & 3 & 3 & 3 \\
Merica (g) & 2 & 2 & 2 & 2 \\
Penyedap rasa (g) & 2 & 2 & 2 & 2 \\
Garam (g) & 2 & 2 & 2 & 2 \\
Air es (ml) & 60 & 60 & 60 & 60 \\
\hline
\end{tabular}

\section{Pembuatan Tepung Mengkudu}

Pembuatan tepung mengkudu dikupas, direndam dengan air garam, dicuci, dipotong berbentuk dadu, ditiriskan, dikeringkan dalam oven pada suhu $60^{\circ} \mathrm{C}$ selama 72 jam setelah itu digiling hingga menjadi tepung kemudian diayak. Adapun bagan alir proses pembuatan tepung buah mengkudu pada gambar 1 sebagai berikut :

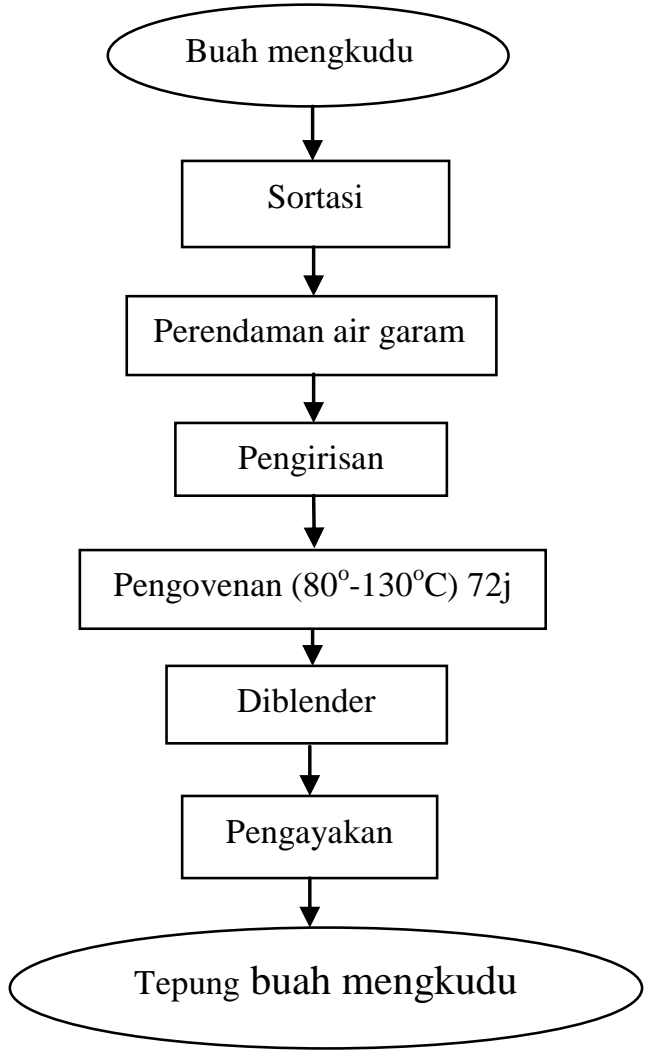

Gambar 1. Bagan alir proses pembuatan tepung buah mengkudu

\section{Cara Pembuatan Burger IkanTuna}

Cara pembuatan burger ikan tuna yaitu daging dibersihkan dengan cara memisahkan ingsan, isi perut, daging dari tulang, kemudian dicuci bersih selanjutnya dipotong kecil, daging 
digiling menggunakan food prosessor, ditambahkan garam, bawang putih, bawang merah, masako, merica dan es batu kemudian digiling. Menambahkan tepung tapioka dan tepung mengkudu dengan presentase, $0 \%, 2,5 \%$, $5 \%, 7,5 \%$, adonan dimasukan ke dalam talenan, dikukus selama 20 menit dengan suhu $80^{\circ} \mathrm{C}$, setelah itu adonan dibentuk menjadi bulatan setebal $1,5 \mathrm{~cm}$, kemudian masukan dan diamkan selama satu malam dalam freezer, daging burger dipanggang pada suhu $130^{\circ} \mathrm{C}$ selama 25 menit. Diagram alir pembuatan burger terlihat pada gambar 2 sebagai berikut:

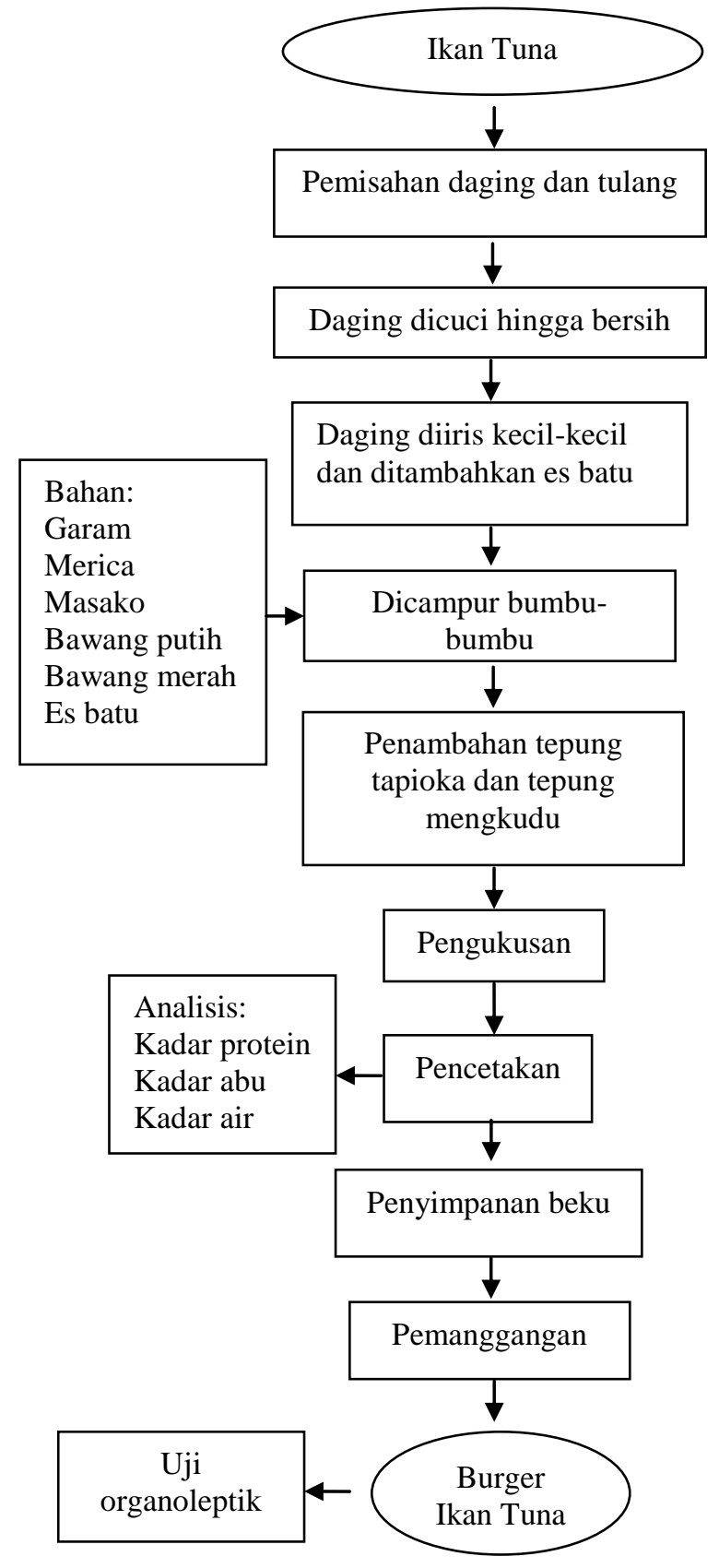

\section{Pengamatan}

Variabel yang diamati adalah : kadar protein, kadar abu, kadar air dan uji organoleptik : warna, rasa, aroma, dan tekstur.

Kadar Protein (AOAC, 1999)

Ditimbang contoh sebanyak $0,5 \mathrm{~g}$ dan dimasukan dalam labu kjeldhal dan tambahkan $2 \mathrm{~g}$ campuran $\mathrm{K}_{2} \mathrm{SO}_{4}$ dan $\mathrm{CuCO}_{4}$ dengan perbandingan 1:1 serta $5 \mathrm{ml} \mathrm{H}_{2} \mathrm{SO}_{4}$ secara hatihati, lalu didestilasi sampai cairan berwarna hijau jernih dan biarkan dingin. Tambahkan $10 \mathrm{ml}$ aquadest dan dipindahkan kelabu suling. Tambahkan $10 \mathrm{ml} \mathrm{NaOH} 40 \%$ atau lebih sampai terbentuk warna hitam dan segera didestilasi. Hasil penyulingan ditampung dalam erlenmeyer berisi 25-50 ml $\mathrm{H}_{2} \mathrm{SO}_{4} \quad 0,02 \mathrm{~N}$ dan 3 tetes indikator mengsel (425 mg metil red dan $500 \mathrm{mg}$ metilen blue yang dilarutkan dalam alkohol $96 \%$. Hasil destilasi dititrasi dengan larutan $\mathrm{NaOH} 0,02$ $\mathrm{N}$ sampai terjadi perubahan warna dan dilakukan hal yang sama untuk blanko (tanpa bahan).

Kadar protein $=\underline{(b-c) \times N \times 0,014 \times \text { FK x } 100 \%}$ a

Keterangan : $\quad \mathrm{A}=$ berat sampel $\mathrm{g}$

$$
\mathrm{B}=\text { hasil titrasi sampel } \mathrm{ml}
$$$$
\mathrm{C}=\text { hasil titrasi blanko } \mathrm{ml}
$$

Kadar Abu (Sudarmadji, $d k k .$, 1989)

Kadar abu ditetapkan dengan cara membakar bahan dalam muffle. Contoh yang telah dikeringkan diambil sebanyak $5 \mathrm{~g}$ dan dimasukan dalam muffle, dibakar pada suhu $100^{\circ} \mathrm{C}$ selama $1 \mathrm{jam}$ dan dilanjutkan dengan suhu $300^{\circ} \mathrm{C}$ selama $2 \mathrm{jam}$. Didinginkan kemudian ditimbang dan dihitung kadar abu dengan rumus :

$$
\begin{array}{cc}
\text { Kadar abu }(\%)=--------------x ~ 100 \% \\
\text { Keterangan : } & \text { A = berat awal }(\mathrm{g}) \\
& \mathrm{B}=\text { berat akhir }(\mathrm{g})
\end{array}
$$

Kadar Air (Sudarmadji, $d k k .$, 1989)

Kadar air ditetapkan dengan cara memanaskan bahan sebanyak $10 \mathrm{~g}$ dalam water bath selama 30 menit dalam oven pada suhu $105^{\circ} \mathrm{C}$ selama $2 \mathrm{jam}$. Kemudian didinginkan dalam desikator selama 15 menit kemudian ditimbang. Diamati sampai diperoleh berat yang konstan. Ditentukan kadar air bahan dengan rumus :

$$
\begin{aligned}
\operatorname{Kadar} \operatorname{Air}(\%) & =\mathrm{A}-\mathrm{B} \\
\text { Keterangan: A } & =\text { berat awal } \\
\mathrm{B} & =\text { berat akhir (setelah pengeringan) }
\end{aligned}
$$




\section{Uji Organoleptik (Soekarto, 1985)}

Panel yang digunakan dalam pengujian organoleptik ini adalah panelis tidak terlatih berjumlah 20 orang. Uji organoleptik dilakukan dengan menggunakan uji hendonik/uji kesukaan meliputi warna, rasa, aroma dan tekstur tingkat kesukaan. Adapun format pengisian uji organoleptik burger ikan tuna, seperti disajikan pada Tabel 2.

Nama Panelis :

Hari Tanggal :

Produk : Burger Ikan Tuna

UjiOrganoleptik:

(Warna/Rasa/Aroma/Tekstur)

Tabel 2. Pengujian organoleptik burger ikan tuna

\begin{tabular}{ccccc}
\multirow{2}{*}{$\begin{array}{c}\text { Mutu } \\
\text { Organoleptik }\end{array}$} & \multicolumn{4}{c}{ Kode Produk Burger Ikan } \\
\cline { 2 - 5 } & B1x1 & B2x1 & B3x1 & B4x1 \\
\hline
\end{tabular}

\section{Warna}

Rasa

\section{Aroma}

Tekstur

\section{Keterangan:}

Skala Hendonik

Sangat Suka $\quad=5$

Suka $\quad=4$

Agak Suka $\quad=3$

Tidak Suka $\quad=2$

Sangat Tidak Suka $\quad=1$

\section{Hasil dan Pembahasan}

\section{Karakteristik Kimia}

Kadar Protein (\%)

Rata-rata kadar protein (\%) disajikan pada

Tabel 3 sebagai berikut:

Tabel 3. Rerata kadar protein (\%) burger ikan tuna

\begin{tabular}{|c|c|c|}
\hline Perlakuan & Rata-rata & $\begin{array}{l}\text { BNT } \alpha= \\
0.05\end{array}$ \\
\hline $15 \%+0 \%$ & $12,35^{\mathrm{c}}$ & \multirow{4}{*}{4.38} \\
\hline $12.5 \%+2.5 \%$ & $13,30^{\mathrm{b}}$ & \\
\hline $10 \%+5 \%$ & $13,57^{\mathrm{b}}$ & \\
\hline $7.5 \%+7.5 \%$ & $14,67^{\mathrm{a}}$ & \\
\hline $\begin{aligned} & \text { Keterangan: Angka- } \\
& \text { sama } \\
& \text { berpen } \\
& 0.05\end{aligned}$ & $\begin{array}{l}\text { yang diikut } \\
\text { kolom yang } \\
\text { sangat nyat: }\end{array}$ & $\begin{array}{l}\text { ngan huruf yang } \\
\text { ma menunjukan } \\
\text { da uji BNT } \alpha=\end{array}$ \\
\hline
\end{tabular}

Hasil analisis ragam menunjukan bahwa perlakuan memberikan pengaruh nyata terhadap ( $>0,05)$, terhadap kadar protein (\%) burger ikan tuna yang disubtitusikan dengan tepung buah mengkudu.

Hasil uji beda nyata terkecil (BNT) kadar protein (\%) burger ikan tuna yang disubtitusikan dengan tepung buah mengkudu menunjukan bahwa perlakuan B4 (tepung mengkudu 7,5\% + tepung tapioka 7,5\%) adalah berbeda dan lebih baik dibandingkan perlakuan B1 (tepung mengkudu $0 \%$ + tepung tapioka 15\%), B2 (tepung mengkudu 2,5\% + tepung tapioka $12,5 \%$ ) dan B3 (tepung mengkudu 10\% + tepung tapioka 5\%). Terjadinya hal ini karena semakin tinggi pemberian tepung mengkudu, kandungan protein semakin meningkat karena buah mengkudu mengandung protein yang cukup tinggi yaitu 58,67\% (Sarwono, 2002).

Protein merupakan senyawa makronutrien bermolekul besar yang tersusun dari unsur-unsur $\mathrm{C}, \mathrm{H}, \mathrm{O}, \mathrm{N}, \mathrm{S}$, dan kadang-kadang $\mathrm{P}, \mathrm{Fe}, \mathrm{Cu}$ sebagai senyawa kompleks dalam protein (Sudarmadji $d k k .$, 1989). Fungsi protein antara lain adalah sebagai pembangun struktur utama dalam sel, enzim dalam membran, hormon dan alat pembawa. Dilihat dari sisi nutrisi, protein merupakan sumber energi dan asam amino yang penting untuk pertumbuhan dan perbaikan sel (Susanto dan Fahmi, 2012). Berdasarkan SNI 01-6683-2002 tentang burger, kadar protein minimal burger sebesar $12 \%(\mathrm{wb})$, sehingga kadar protein burger ikan tuna memenuhi persyaratan SNI, karena memiliki kadar protein sebesar $14,90 \%$ (wb). Tingginya protein B4 disebabkan oleh kadar protein tepung mengkudu yang lebih tinggi daripada tepung tapioka pada perlakuan B4 burger yang disubtitusi dengan tepung mengkudu $7,5 \%+$ tepung tapioka $7.5 \%$.

\section{Kadar Air (\%)}

Data pengamatan rata-rata kadar air (\%) disajikan pada Tabel 4. sebagai berikut:

Tabel 4. Rerata kadar air (\%) burger ikan tuna

\begin{tabular}{lcc}
\hline Perlakuan & Rata-rata & $\begin{array}{l}\text { BNT } \alpha= \\
0.05\end{array}$ \\
\hline $15 \%+0 \%$ & $70,875^{\mathrm{a}}$ & \\
$12.5 \%+2.5 \%$ & $70,5575^{\mathrm{a}}$ & 2.32 \\
$10 \%+5 \%$ & $68,455^{\mathrm{b}}$ & \\
$7.5 \%+7.5 \%$ & $63,32^{\mathrm{b}}$ \\
\hline Keterangan: Angka yang diikuti huruf yang sama pada baris \\
\multicolumn{3}{l}{ yang sama menunjukan bepengaruh sangat } \\
nyata pada uji BNT $\alpha=0.05$
\end{tabular}


Hasil analisis ragam menunjukan bahwa perlakuan memberikan pengaruh nyata terhadap ( $>0,05)$, terhadap kadar air (\%) burger ikan tuna yang disubtitusi dengan tepung buah mengkudu.

Hasil uji beda nyata terkecil (BNT) kadar air (\%) burger ikan tuna yang disubtitusi dengan tepung buah mengkudu menunjukan bahwa perlakuan B3 (tepung mengkudu 5\% dan tepung tapioka 10\%) dan B4 (tepung mengkudu 7,5\% + tepung tapioka 7,5\%) adalah berbeda dan $(\mathrm{p}<63.32)$ dibandingkan perlakuan B1 (tepung mengkudu $0 \%$ + tepung tapioka 15\%), B2 (tepung mengkudu 2,5\% + tepung tapioka $12,5 \%)$. Dikarenakan semakin tinggi pemberian tepung mengkudu, tepung tapioka dan pada proses pengukusan menyebabkan kehilangan air dalam produk (Ali, 2004). Menurut SNI burger 01-6683-2002, kadar air maksimal burger yaitu $60 \%$ (wb). Kadar air burger ikan B1, B2, B3, dan B4 tidak memenuhi persyaratan SNI karena memiliki kadar air lebih besar dari 60\% (wb). Pada penelitian sebelumnya oleh Olivia $d k k$., (2013) subsitusi tepung terigu oleh tepung kulit udang dogol tidak mempengaruhi kadar air burger. Bahan penyusun merupakan faktor yang dapat mempengaruhi kadar air suatu produk pangan. Kadar air ikan tongkol sebagai bahan baku burger yaitu 72\% (Suwamba, 2008 dalam Atmaja, 2009). Bahan pengisi (filler) yang digunakan juga dapat mempengaruhi kadar air burger, karena filler yang berupa tepung dapat meningkatkan kemampuan mengikat air (Afrisanti ,2010).

\section{Kadar Abu (\%)}

Data pengamatan rata-rata kadar abu (\%) disajikan pada Gambar 3, sebagai berikut:

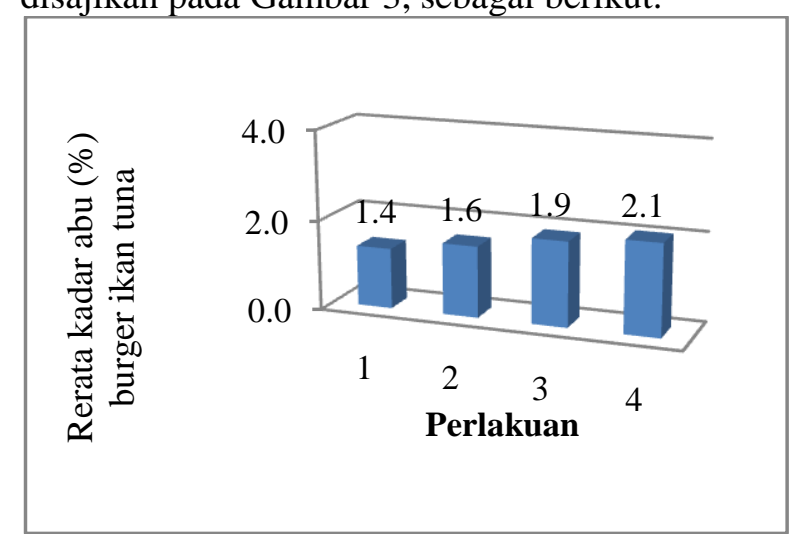

Gambar 3. Rata-rata kadar abu burger ikan tuna

Hasil analisis ragam menunjukan bahwa perlakuan memberikan pengaruh tidak nyata terhadap ( $\mathrm{p}>0,05)$, terhadap kadar abu (\%) burger ikan tuna yang disubtitusikan dengan tepung buah mengkudu.

Uji statistik menunjukan bahwa kadar abu (\%) burger ikan tuna yang disubtitusikan dengan tepung buah mengkudu menunjukan bahwa perlakuan B4 (tepung mengkudu 7,5\% + tepung tapioka 7,5\%) adalah berbeda dan $(\mathrm{p}<8.20)$ dibandingkan perlakuan B1 (tepung mengkudu $0 \%$ + tepung tapioka 15\%), B2 ( tepung mengkudu 2,5\% + tepung tapioka 12,5\%) dan B3 (tepung mengkudu $5 \%$ + tepung tapioka 10\%). Dikarenakan unsur-unsur mineral yang dikenal dengan kadar abu yang berfungsi sebagai zat pembangun dan pengatur. Kadar abu burgerberkisar antara 4,86\% - 6,45\% (wb). Sarwono, 2002. Mengatakan tepung mengkudu memiliki kadar abu sebesar 5,4\%, lebih tinggi dibandingkan dengan tepung terigu yaitu sebesar $1,9 \%$. Kadar abu pada tepung mengkudu yang digunakan pada proses pembuatan burger yaitu sebesar $2.05 \%$. Ikan tuna sebagai bahan baku utama pada proses pembuatan burger memiliki kadar abu $1.4 \%$, serta kandungan vitamin dan mineral sebesar 1\% (Junianto, 2003).

\section{Karakteristik Sensoris Burger Ikan Tuna}

\section{Warna}

Data pengamatan karakteristik burger ikan tuna yang disubtitusi dengan tepung buah mengkudu berdasarkan hasil analisis sidik ragam burger ikan tuna menunjukan tidak berpengaruh nyata terhadap warna burger yang dihasilkan. Seperti terlihat pada gambar 4 sebagai berikut:

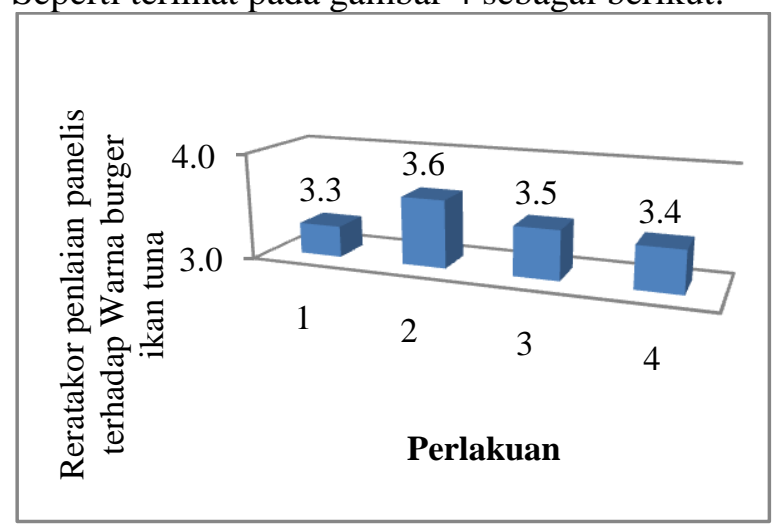

Gambar 4. Rata - rata warna burger ikan tuna

Hasil analisis ragam menunjukan bahwa perlakuan memberikan pengaruh tidak nyata $(p<0.01)$ terhadap warna burger ikan tuna yang disubtitusi dengan tepung buah mengkudu.

Berdasarkan hasil pengamatan dapat kita ketahui bahwa perlakuan B1 (tepung mengkudu $0 \%+$ tepung tapioka 15\%), B2 (tepung 


\section{Jurnal Pengolahan Pangan 3 (1) 1-8}

mengkudu $2.5 \%+$ tepung tapioka $12.5 \%$ ), B3 (TM 5\% + TT 10\%) dan B4 (TM 7,5\% +TT $7.5 \%)$ tidak berpengaruh nyata pada tingkat kesukaan panelis terhadap warna burger ikan tuna. Rata-rata nilai yang diperoleh $3,6 \%$ yaitu pada B2 (tepung mengkudu $2.5 \%$ + tepung tapioka $12.5 \%$ ) sedangkan pada perlakuan B1 (tepung mengkudu $0 \%$ + tepung tapioka 15\%), B3 (tepung mengkudu 5\% + tepung tapioka 10\%) dan B4 (tepung mengkudu 7.5\% + tepung tapioka $7.5 \%)$ menghasilkan nilai lebih rendah $(3,3 \%)$, $(3,5 \%)$ dan $(3,4 \%)$. Hasil penelitian ini memberikan gambaran bahwa semakin tinggi penambahan tepung buah mengkudu tidak dapat mempengaruhi warna burger ikan tuna yang dihasilkan.

Terjadinya hal ini disebabkan oleh warna coklat yang dihasilkan dari tepung mengkudu. Pengaruh tepung tapioka sebagai filler tidak akan mengubah warna asli dari burger ikan tuna karena warna pada tepung mengkudu adalah coklat kepucatan. Warna makanan memiliki peranan utama dalam penampilan makanan, meskipun makanan tersebut lezat, tetapi bila penampilan tidak menarik waktu disajikan akan mengakibatkan selera orang yang akan memakannya menjadi hilang (Soeparno, 2005). Warna merupakan refleksi cahaya pada permukaan bahan yang ditangkap oleh indra penglihatan dan ditranmisi dalam sistem syaraf. Perubahan warna dapat ditentukan oleh pembuatan bahan kimia dan perombakan enzim menjadi pigmen. Warna mempengaruhi penerimaan suatu bahan pangan, karena umumnya penerimaan bahan yang pertama kali dilihat adalah warna. Warna yang menarik akan meningkatkan penerimaan produk. Pada saat pemasakan warna bahan atau produk pangan dapat berubah. Hal ini dapat disebabkan oleh hilangnya sebagian pigmen akibat pelepasan cairan sel pada saat pemasakan atau pengolahan, intensitas warna semakin menurun (Elviera, 1998). Warna produk burger dipengaruhi oleh kualitas warna bahan baku (daging).

\section{Rasa}

Data pengamatan rasa burger ikan tuna yang disubtitusi dengan tepung buah mengkudu hasil analisis sidik ragam burger ikan tuna menunjukan bahwa tidak berpengaruh nyata terhadap rasa burger yang dihasilkan, seperti terlihat pada Gambar 5 berikut:
e-ISSN : 2621-6973

p-ISSN : 2527-5631

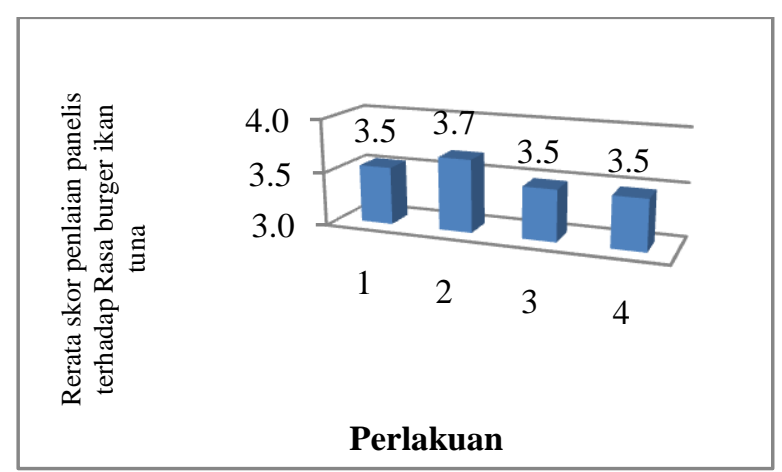

Gambar 5. Rata-rata skor penilaian panelis terhadap rasa burger ikan tuna

Hasil analisis ragam menunjukan bahwa perlakuan tidak berpengaruh nyata terhadap rasa burger ikan tuna yang disubtitusi dengan tepung mengkudu pada perlakuan B2 (tepung mengkudu $2.5 \%$ + tepung tapioka $12.5 \%$ ) dan B1 (tepung mengkudu $0 \%$ + tepung tapioka $15 \%$ ), dengan skor $(3,5)$ dan $(3,4)$ agak suka.

Diduga tepung mengkudu memiliki rasa negatif pada produk burger ikan tuna, dimana panelis rata-rata sangat suka. Rasa makanan dapat dikenali dan dibedakan oleh kuncupkuncup cecapan yang terletak pada papila yaitu noda merah jingga pada lidah. Faktor yang mempengaruhi rasa yaitu senyawa kimia, suhu, konsistensi dan interaksi pangan dengan komponen rasa yang lain serta jenis dan lama pemasakan. Atribut rasa banyak ditentukan oleh formulasi yang digunakan dan kebanyakan tidak dipengaruhi oleh pengolahan suatu produk pangan (Winarno, 1997). Menurut Surjana (2001), umumnya ada tiga macam rasa yang sangat menentukan penerimaan konsumen yaitu kegurihan, keasinan, dan rasa daging. Tingkat kegurihan produk burger dipengaruhi oleh kadar garam dan kadar daging, semakin tinggi kadar daging maka kegurihannya akan semakin tinggi.

\section{Aroma}

Data pengamatan aroma burger ikan tuna yang disubtitusi dengan tepung buah mengkudu hasil analisis sidik ragam burger ikan tuna menunjukan bahwa tidak berpengaruh nyata terhadap aroma burger yang dihasilkan. Seperti terlihat pada Gambar 6 sebagai berikut: 
Jurnal Pengolahan Pangan 3 (1) 1-8

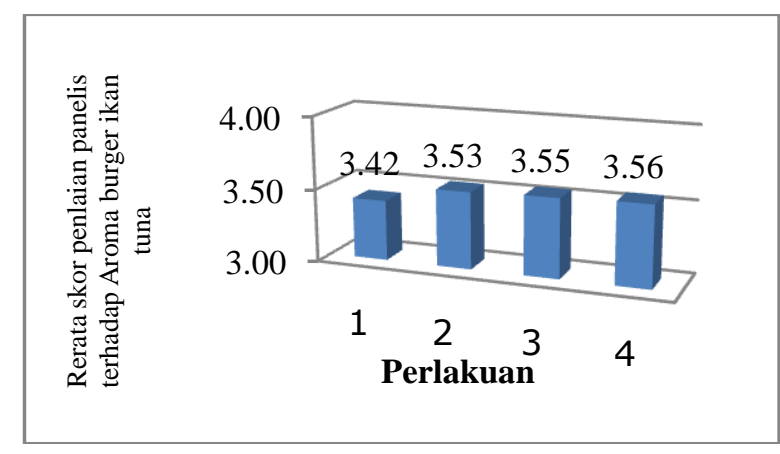

Gambar 6. Rata-rata skor penilaian panelis terhadap aroma burger ikan tuna

Hasil analisis ragam menunjukan bahwa perlakuan pemberian tidak pengaruh nyata $(p<0,01)$ terhadap aroma burger ikan yang disubtitusi dengan tepung mengkudu pada perlakuan B2 (tepung mengkudu $2.5 \%+$ tepung tapioka $12.5 \%$ ) dan B1 (tepung mengkudu $0 \%+$ tepung tapioka $15 \%)$, dengan skor $(3,53 \%)$ dan $(3,42 \%)$ agak suka.

Diduga tepung mengkudu memiliki aroma baik pada produk burger ikan tuna, dimana panelis rata-rata suka. Aroma adalah faktor paling penting pada daging. Aroma sukar untuk didefinisikan secara objektif. Evaluasi aroma dan rasa masih tergantung pada pengujian secara sensori (tes panel). Keragaman antara individu dalam respon intensitas dan kualitas terhadap stimulus tertentu menyebabkan pemilihan anggota panel menjadi penting (Lawrie, 2003). Pembauan disebut pencicipan jarak jauh karena manusia dapat mengenal enaknya makanan yang belum terlihat hanya dengan mencium aromanya dari jarak jauh (Soekarto, 1990). Jenis daging yang digunakan, lemak intramuskular, bahanbahan yang ditambahkan selama pemasakan serta jumlah tepung yang terlalu tinggi akan mempengaruhi aroma burger, penggunaan tepung yang terlalu banyak akan menutupi aroma daging pada burger sehingga disukai oleh panelis (Purnomo, 1990).

\section{Tekstur}

Berdasarkan hasil analisis sidik ragam burger ikan tuna menunjukan bahwa tidak berpengaruh nyata terhadap tekstur burger yang dihasilkan, seperti terlihat pada Gambar 7 berikut:
e-ISSN : 2621-6973

p-ISSN : 2527-5631

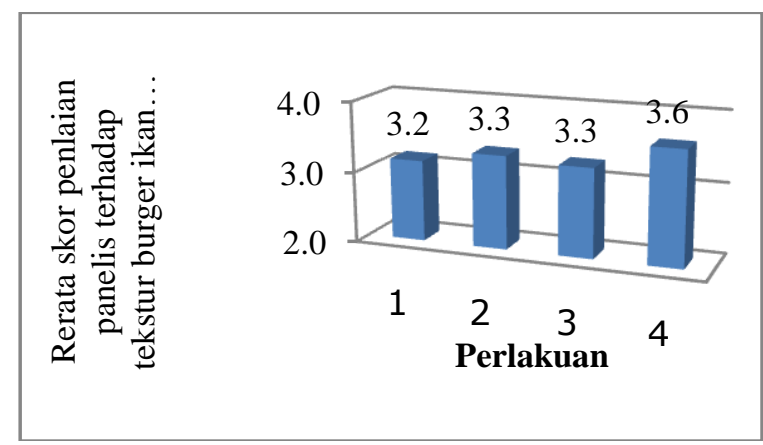

Gambar 7. Rata-rata skor penilaian panelis terhadap tekstur burger ikan

Hasil analisis ragam menunjukan bahwa perlakuan pemberian pengaruh tidak nyata $(\mathrm{p}<0,01)$ terhadap tekstur burger ikan yang disubtitusi dengan tepung mengkudu. Hasil uji statistik menunjukan bahwa perlakuan B4 (tepung mengkudu $7.5 \%$ + tepung tapioka $7.5 \%$ ) dan B3 (tepung mengkudu 5\% + tepung tapioka $10 \%$ ) dan B2 (tepung mengkudu $2.5 \%$ + tepung tapioka $12.5 \%)$, dengan skor $(3,6 \%),(3,3 \%)$ dan $(3,3 \%)$. Sedangkan pada perlakuan B1 (tepung mengkudu $0 \%+$ tepung tapioka 15\%) memberikan nilai lebih rendah $(3,2 \%)$.

Diduga semakin tinggi penambahan tepung mengkudu pada burger ikan tuna mempengaruhi tekstur yang lebih disukai oleh panelis. Tekstur makanan berhubungan dengan sifat aliran dan deformasi produk serta cara berbagai struktur unsur dan struktur komponen ditata dan digabung menjadi mikro dan makro struktur (Deman, 1989).

\section{Kesimpulan}

Berdasarkan hasil penelitian dapat disimpulkan bahwa:

1. Penggunaan tepung mengkudu sebagai subtitusi tepung tapioka $7.5 \%$ dapat meningkatkan kadar protein burger ikan tuna sebesar $14.66 \%$, kadar air $70.55 \%$, dan kadar abu $2.05 \%$.

2. Penambahan tepung mengkudu sebagai subtitusi tepung tapioka hingga $7.5 \%$ memberikan aroma, rasa, warna, dan tekstur relatif sama pada semua perlakuan disukai oleh panelis.

\section{Daftar Pustaka}

Abustam dan Ali, 2004. Pengolahan Daging. Fakultas Peternakan Universitas Hasanuddin, Makassar. 
Jurnal Pengolahan Pangan 3 (1) 1-8

AOAC, 1999. Official methods of the association of analytical chemis, Washington, D. C.

Afrisanti, D. W. 2010. Kualitas Kimia dan Organoleptik Burger Daging dengan Penambahan Tepung Tempe. Skripsi Program Studi Peternakan, Fakultas Pertanian, Universitas Sebelas Maret. Surakarta.

Atmaja,A.K.2009. Aplikasi Asap Cair Redestilasi pada Karakterisasi Kamaboko Ikan Tongkol (Euthynus Affinis). Ditinjau dari Tingkat Keawetan dan Kesukaan Konsumen. Skripsi Program Studi Teknologi Hasil Pertanian, Fakultas Pertanian, Universitas Sebelas Maret Surakarta.

Deman, J. M. 1989. Kimia Makanan. ITB Press. Bandung.

Elviera, G. 1998. Pengaruh pelayuan daging sapi terhadap mutu bakso sapi. Skripsi. Fakultas Teknologi Pertanian, Institut Pertanian Bogor, Bogor.

Hardiman, 2011. Aneka Burger Bungkus. Penerbit PT. Gramedia Pustaka Utama. Jakarta.

Junianto, 2003. Teknik Penanganan Ikan. Penebar Swadaya. Jakarta.

Lawrie, R. A. 2003. Ilmu Daging. Terjemahan A. Parakkasi. Universitas Indonesia Press, Jakarta.

Olivia R., Lorensia M.E.P., dan Fransiskus S.P. 2013. Substitusi Tepung Kulit Udang Dogol (Metapenaeus monoceros Fab) dalam pembuatan Nuget Jamur Tiram (Pleurotusos treatus Jacq). Fakultas Teknobiologi, Universitas Atmajaya. Yogyakarta.
e-ISSN : 2621-6973

p-ISSN : 2527-5631

Purnomo, H. 1990. Kajian mutu, di daerah Bogor. Skripsi. Fakultas Teknologi Pertanian, Institut Pertanian Bogor, Bogor.

Sarwono 2002. Khasiat dan manfaat mengkudu. Cetakan ke-3. Agromedia Pustaka, Jakarta.

Sarwono, 2010. Usaha Membuat Tempe dan Oncong. Penebar Swadaya. Jakarta.

Soekarto, S.T. 1990. Dasar-dasar Pengawasan dan Standarisasi Mutu Pangan. Institut Pertanian Bogor Press, Bogor.

Soekarto, 1985. Penilaian Organoleptik Untuk Industri Pangan dan Hasil Pertanian. Pusat Pengembangan Teknologi Pangan, IPB, Bogor.

Soeparno. 2005. Ilmu dan Teknologi Daging. Universitas Gajah Mada Press, Yogyakarta.

Sudarmadji, S.,Horyono B.S. dan Suhardi.1989. Analisa Bahan Makanan dan Pertanian. PAU Pangan dan Gizi UGM. Yogyakarta.

Surjana W., 2001. Pengawetan bakso daging sapi dengan bahan aditif kimia pada penyimpanan suhu kamar. Skripsi. Fakultas Teknologi Pertanian. Institut Pertanian Bogor, Bogor.

Susanto, E., dan A.S. Fahmi. 2012. Senyawa Fungsional dari Ikan: Aplikasinya dalam Pangan. Jurnal Aplikasi Teknologi Pangan, Vol. 1, No. 4.

Winarno. F.G. 1997. Kimia pangan dan gizi. Gramedia Pustaka Utama. Jakarta. 